\title{
Thermal Effect on the Life-cycle Parameters of the Medically Important Freshwater Snail Species Lymnaea (Radix) luteola (Lamarck)
}

\begin{abstract}
Md Abdul Aziz, SK Raut
Ecology and Ethology Laboratory, Department of Zoology, University of Calcutta, 35 Ballygunge Circular Road, Calcutta 700 019, India

The snails Lymnaea (Radix) luteola exhibited marked variations in growth, longevity, and attaining sexual maturity at different temperatures and diets. At $10^{\circ} \mathrm{C}$, irrespective of foods, $\mathrm{pH}$ and salinity of water, the snails had minimum life span, maximum death rate and lowest growth rate. At $15^{\circ} \mathrm{C}$, the growth rate was comparatively higher and the snails survived for a few more days. But at these temperatures they failed to attain sexual maturity. Snails exposed to $\mathrm{pH} 5$ and 9 at $20^{\circ}, 25^{\circ}, 30^{\circ}, 35^{\circ} \mathrm{C}$ and room temperatures $\left(19.6^{\circ}-29.6^{\circ} \mathrm{C}\right)$; to $0.5,1.5$ and $2.5 \mathrm{NaCl} \%$ o at $20^{\circ}$ and $35^{\circ} \mathrm{C}$; to $2.5 \mathrm{NaCl} \%$ o at $25^{\circ} \mathrm{C}$ and room temperatures failed to attain sexual maturity. The snails exposed to $\mathrm{pH} 7$ and different salinity grades at $20^{\circ}, 25^{\circ}, 30^{\circ}, 35^{\circ} \mathrm{C}$ and room temperatures became sexually mature between $25-93$ days depending upon the type of foods used in the culture.
\end{abstract}

Key words : Lymnaea (Radix) luteola - life-cycle parameters - temperature - food - pH - salinity - India

Lymnaeids are distributed worldwide (Godan 1983). They have drawn the attention of a large number of researchers because of their role as hosts for larval stages of the helminth parasites which cause disease in man and domestic animals (Liston \& Soparkar 1918, Rao 1933, Chatterjee 1952, Malek \& Cheng 1974, Ghosh \& Chauhan 1975, Godan 1983, Burch 1985, Raut 1986). Considering their involvement in regulating the life-cycle of the worm parasites various aspects of the biology and ecology of these freshwater gastropod snails were studied by Seshaiya (1927), Noland and Carriker (1946), Kendall (1953), McCraw (1970), Berrie (1965), Burla and Speich (1971). Van der Steen et al.(1973), Hunter (1975) Raut et al. (1992), Raut and Misra (1993), and Misra and Raut (1993) with a view to developing methods for control. Although additional information on ecology of lymnaeids is available (Jong-Brink 1990, Moens 1991) an effective control device for these snail intermediate hosts has not been found. Since the status of individuals of a species is largely determined by the physical, chemical and biological parameters of the ecosystem to which they belong it is most likely that a study on the cumulative influence of these factors would provide us better information on the subject. As most of the

This work received financial support from the Muslim Association for the Advancement of Science (MAAS), India.

Received 30 June 1994

Accepted 10 October 1995 available information is based on the results of experimental studies considering only a single factor (Vaughn 1953, Prinsloo \& Van Eden 1969, 1973, Van der Borght \& Van Puymbroeck 1971, Raut \& Misra 1991,1993, Raut et al. 1992, Saha \& Raut 1992) it has not been possible to regulate the density of these snails through the application of these results. Accordingly, the present study was designed to collect detailed information on the lifecycle parameters viz., the growth rates, the age of attainment to sexual maturity, the duration of reproductive period, the rate of egg production, the death rate and the life span of Lymnaea (Radix) luteola (Lamarck), in order to consider the cumulative effects of these different ecological parameters. Since Lymnaea are adapted to a wide range of temperatures (Walter 1968, Prinsloo \& Van Eeden 1969) the aim was to study the effect of temperature on the snails $L$. (R.) luteola under varying ecological conditions such as food, water $\mathrm{pH}$ and salinity $(\mathrm{NaCl})$. The findings are presented herein.

\section{MATERIALS AND METHODS}

Eighty-one healthy, sexually mature $L$. $(R$.) luteola were collected from the pond located in the Ballygunge Science College campus, Calcutta University on 18 March 1991. They were released into an aquarium $30 \times 20 \times 25 \mathrm{~cm}$, containing pond water, $20 \mathrm{~cm}$ in depth. A few examples of Chara, Vallisneria and Ipomoea were also released into the water of the aquarium to provide resting and egg laying sites for the snails. The snails were regularly supplied with lettuce leaves, as food. The 
snails started egg-laying within a few days. The egg capsules were collected on a daily basis from the aquarium, and kept inside a glass jar (1000 ml capacity) containing pond water. In one glass jar 7-10 egg capsules deposited within a $24 \mathrm{hr}$ period, were kept together. The water in the glass jars was changed regularly with fresh pond water. Through regular observation newly hatched (zero-day-old) snails were taken daily from the jars. The required number of individuals, when available, were studied. These newly hatched snails were placed in a plastic container ( 21 capacity) containing pond water. The containers were kept at $10^{\circ}, 15^{\circ}, 20^{\circ}, 25^{\circ}, 30^{\circ}$ and $35^{\circ} \mathrm{C}\left( \pm 1^{\circ} \mathrm{C}\right)$ temperatures (maintained in Biological Oxygen Demand Chamber), and at room temperature (19.6 $6^{\circ}$ $29.6^{\circ} \mathrm{C}$ ) in order to study the effect of these temperatures on the $L$. (R.) luteola. The experiments were conducted (i) using five different types of food viz. lettuce (Lactuca sativa), mustard (Brassica nigra), radish (Raphanus sativus), spinach (Spinacea oleracea) and aquatic weeds (Chara, Vallisneria), (ii) by maintaining three different levels of $\mathrm{pH}$, viz. 5, 7 and 9 in the culture water and (iii) by maintaining three different grades of salinity viz $0.5,1.5$ and $2.5 \mathrm{NaCl} \%$. The snails under experimental study with different $\mathrm{pH}$ and salinity grades were fed lettuce. The water in the containers was changed regularly at an interval of $12 \mathrm{hr}$ in order to maintain the $\mathrm{pH}$ and salinity at desired levels. The $\mathrm{pH}$ was maintained by adding $\mathrm{HCl}$ and $\mathrm{NaOH}$, and the salinity was maintained by adding $\mathrm{HCl}$ to the freshly collected pond water at an interval of $12 \mathrm{hr}$. A few examples of Ipomoea were kept in each container to provide resting and egg-laying sites for the snails. Dead snails' faecal pellets and unconsumed food materials were removed every $12 \mathrm{hr}$, at the time of removal of water in each container.

Data on the life-cycle parameters viz. the growth rates, the age of attainment of sexual maturity, the duration of reproductive period, the rate of egg production, the death rate and the life span of the snails was collected regularly. In the course of data collection, attention was paid to record the time taken by the eggs to hatch and the hatchability percentage of the eggs, exposed to different temperatures. Measurements of growth in shell length, shell width and total body weight were taken every two weeks, from ten individuals, selected at random, from the total population. But, when the number was ten or less, all were considered for data collection. In the case of the study of egglaying potential, the total number of egg capsules produced by the snails in the container were recorded daily. The number of eggs present in these capsules was also counted and recorded. In all cases the average was calculated for presentation of final data in respect to the life-cycle parameters considered for study. One-way ANOVA was applied for statistical interpretations of the data. Detailed comparisons of the data by way of ANOVA studies were made following Campbell (1989).

\section{RESULTS}

L. (R.) luteola had different life spans (5.43 64.82 days) when cultured at different temperatures in respect to the type of food they consumed (Fig. 1) and the $\mathrm{pH}$ and salinity of the maintenance water (Fig. 2). They exhibited marked variation in the rates of growth, in shell length, shell breadth and body weight when reared at different temperatures (Fig. 3). In general, body weight increased with the increase of temperature from $10^{\circ}$ to $35^{\circ} \mathrm{C}$, at intervals of $5^{\circ} \mathrm{C}$. But the snails attained maximum body weight per day when maintained at room temperatures. Though a similar trend in the growth rates in shell length and shell width is noted in snails maintained from $10^{\circ}$ to $30^{\circ} \mathrm{C}$, slight variations in the rate of increase were seen in individuals exposed to $35^{\circ} \mathrm{C}$ and room temperatures. The snails cultured at $35^{\circ} \mathrm{C}$ with mustard leaves attained maximum shell size $(16 \mathrm{~mm}$ in shell length and $10 \mathrm{~mm}$ in shell width). In contrast to this the lettuce fed individuals exposed to $30^{\circ} \mathrm{C}$ at $0.5 \mathrm{NaCl} \%$ ottained maximum body weight $(4.20$ $\mathrm{mg}$ ) having $15 \mathrm{~mm}$ shell length and $9 \mathrm{~mm}$ shell width.

Among the snails exposed to $10^{\circ} \mathrm{C}$ and $15^{\circ} \mathrm{C}$, irrespctive of the type of food, $\mathrm{pH}$ and salinity of water, and those cultured at $\mathrm{pH} 5$ and 9, irrespective of temperatures, died prior to attaining sexual maturity (Figs 1,2). The snails in the remaining cultures became sexually mature between 25 and 93 days after hatching and the percentages of such snails varied from 6.70 to 70.00 (Figs 1, 2). Individuals maintained at $1.5 \mathrm{NaCl} \%$ under room conditions with lettuce as food, reproduced on an average, only for a period of 8 days, while those reared at $20^{\circ} \mathrm{C}$ with radish leaves as food reproduced for a period of 61.50 days (Figs 1, 2). The rate of egg production varied with the snails in respect to the cultures maintained (Figs 1,2). At room temperature, a lettuce fed snail on an average deposited 0.27 eggs per day but the number was as high as 18.35 in case of lettuce fed snails cultured with $2.5 \mathrm{NaCl} \%$ at $30^{\circ} \mathrm{C}$. The eggs diposited by the snails of different culture stocks required, on an average, 7.0 to 10.50 days to hatch out (Figs 1,2). The percentage of hatching was highest (96.20\%) in eggs deposited by lettuce fed snails kept at room temperature and lowest 
Loituce Mugtard Radish Wpinach Wead
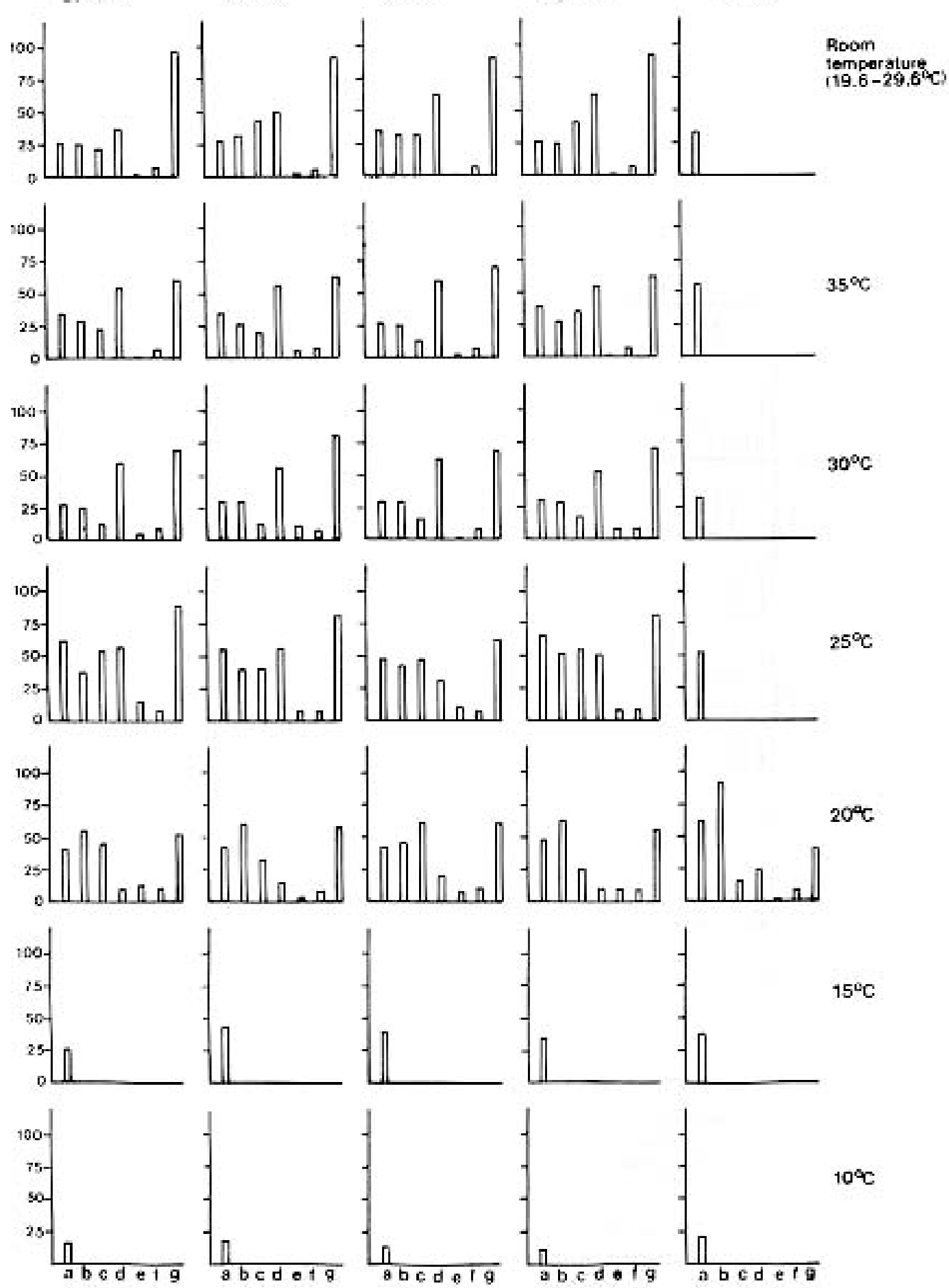

Fig. 1: influence of temperature on the life cycle parameters [a: longevity (in days), b: age of attainment of sexual maturity (in days), c: length of reproduction period (in days), d: snails attained sexual maturity (in per cent), e: rate of egg production (in number), f: developmental period of egg (indays), g: hatchability of egg (in per cent ) ] of Lymnaea (Radix) luteola maintained with five different types of food. 

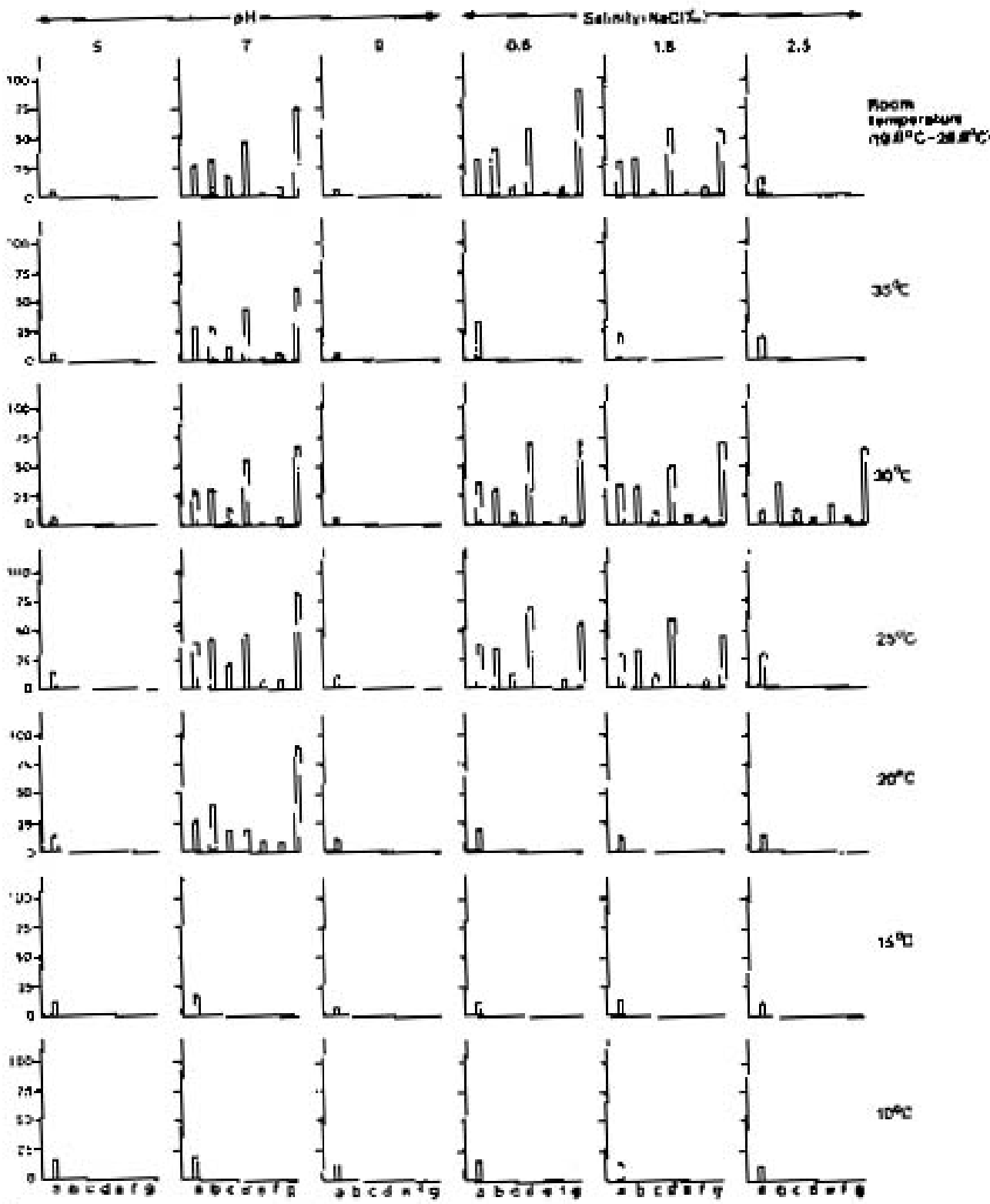

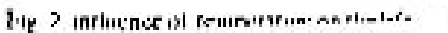

Fig. 2: influence of temperature on the life cycle parameters [a: longevity (in days), b: age of attainment of sexual maturity (in days), c: length of reproduction period (in days), d: snails attained sexual maturity (in percent), e: rate of egg production (in number), $\mathrm{f}$ : developmental period of egg (in days), g: hatchability of egg (in per cent )] of Lymnaea (Radix) luteola maintained at different $\mathrm{pH}$ and salinity with the supply of lettuce food.

(43.70\%) in eggs produced by weed fed snails exposed to $20^{\circ} \mathrm{C}$ (Figs 1, 2). Marked variations have been noted in mortality rates of the snails exposed to different temperatures. The average daily death rate ranged from $0.28 \%$ to $2.72 \%$ (Table I). The snails exhibited the lowest growth rate at $10^{\circ} \mathrm{C}$. An increasing rate of growth is evident with the rise of temperature. Detailed comparisons on the effect of all other higher temperatures in respect to $10^{\circ} \mathrm{C}$ were made by applying ANOVA, to determine the optimum temperature for growth, reproduction and development. From the F values (Table II-IV) it is evident that temperature has significant effect on these events in $L$. (R.) luteola in respect to the type of foods used and the $\mathrm{pH}$ and salinity grades maintained. 


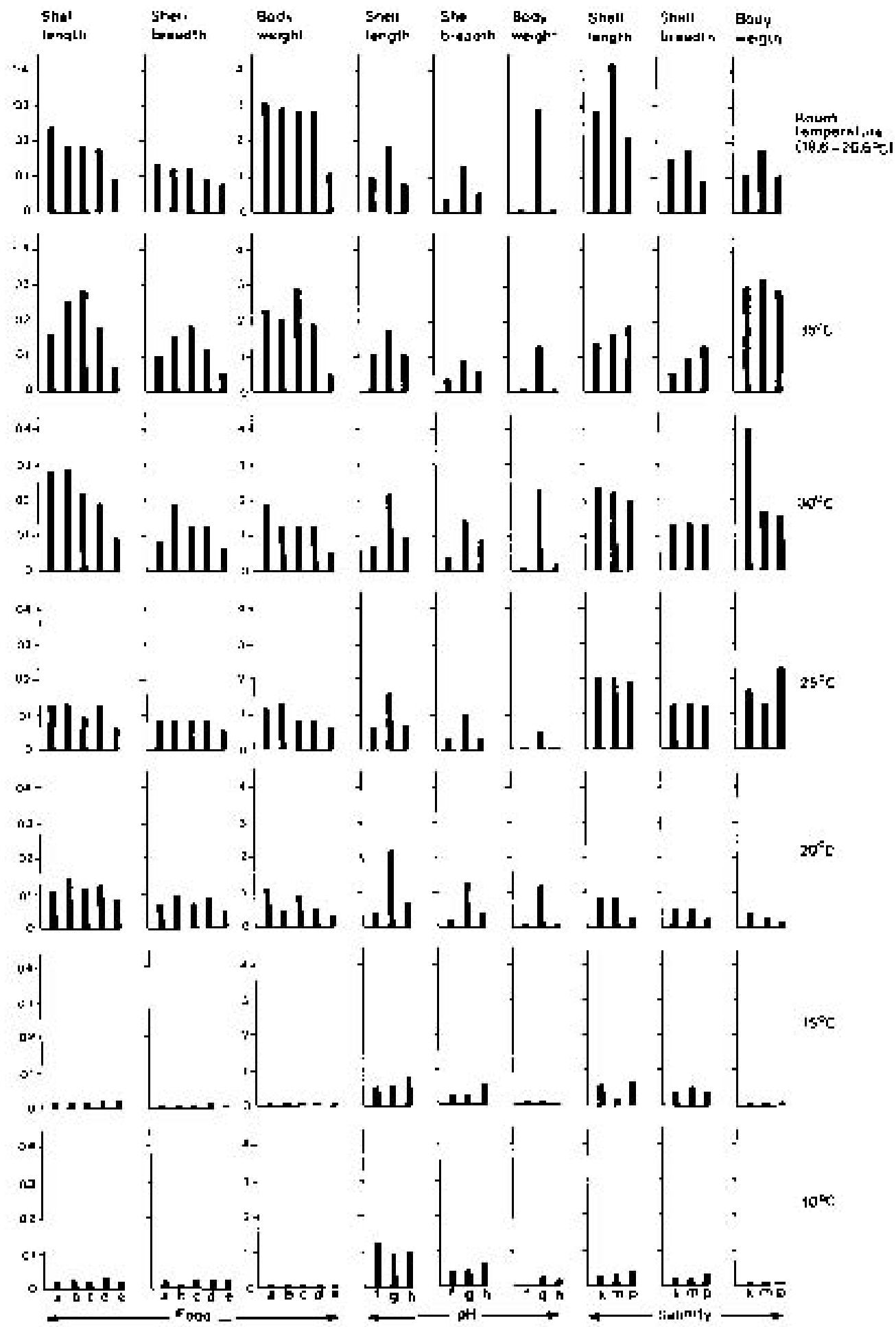

Fig. 3: influence of temperature on the daily rates of growth in shell length $(\mathrm{mm})$, shell breadth $(\mathrm{mm})$ and body weight $(\mathrm{mg})$ of Lymnaea (Radix) luteola maintained with different foods (a: lettuce, b: mustard, c: radish, d: spinach, e :weed), $\mathrm{pH}$ (f:5, g: 7, h:9) and salinity (k: $0.5 \mathrm{NaCl} \%$, m: $1.5 \mathrm{NaCl} \%$, p: $2.5 \mathrm{NaCl} \% o$ ). 
TABLE I

Influence of temperature on the death rates (avarege \% per day) of Lymnaea (Radix) luteola

\begin{tabular}{|c|c|c|c|c|c|c|c|c|c|c|c|}
\hline \multirow{2}{*}{$\begin{array}{c}\text { Temperature } \\
\left({ }^{\circ} \mathrm{C}\right)\end{array}$} & \multicolumn{5}{|c|}{ Food } & \multicolumn{3}{|c|}{$\mathrm{pH}$} & \multicolumn{3}{|c|}{ Salinity $(\mathrm{NaCl} \% o)$} \\
\hline & Lettuce & Mustard & Radish & Spinch & Weed & 5 & 7 & 9 & 0.5 & 1.5 & 2.5 \\
\hline 10 & 1.00 & 0.61 & 1.33 & 1.42 & 0.64 & 1.00 & 0.68 & 1.20 & 0.88 & 0.96 & 1.30 \\
\hline 15 & 0.63 & 0.56 & 0.51 & 0.57 & 0.60 & 1.07 & 0.75 & 1.15 & 0.71 & 0.96 & 1.07 \\
\hline 20 & 0.33 & 0.36 & 0.33 & 0.38 & 0.33 & 1.07 & 0.49 & 1.36 & 0.56 & 0.65 & 0.76 \\
\hline 25 & 0.34 & 0.38 & 0.33 & 0.33 & 0.28 & 1.20 & 0.35 & 1.57 & 0.68 & 0.71 & 0.85 \\
\hline 30 & 0.68 & 0.60 & 0.50 & 0.42 & 0.45 & 2.00 & 0.50 & 2.72 & 0.51 & 0.48 & 0.46 \\
\hline 35 & 0.62 & 0.71 & 0.85 & 0.54 & 0.32 & 2.14 & 0.50 & 2.14 & 0.32 & 0.35 & 0.40 \\
\hline Room & 0.60 & 0.55 & 0.75 & 0.45 & 0.39 & 2.14 & 0.52 & 2.50 & 0.76 & 0.83 & 1.16 \\
\hline
\end{tabular}

\section{DISCUSSION}

Temperature is considered as a critical environmental factor in the ecology of most organisms (Precht et al. 1973, Magnuson et al. 1979, VianeyLiaud 1982, Ahmed \& Raut 1991, Raut et al. 1992). It can act as both a trigger for the commencement of a biological process and as a threshold essential for its continuation. The results of the present study are in agreement with the comment of previous workers so far as the influence of temperature on the biology of $L$.(R.) luteola is concerned. It is evident that $L$. (R.) luteola is unable to complete its life-cycle at $10^{\circ}$ and $15^{\circ} \mathrm{C}$ temperatures, irrespective of the foods it consumes, and the $\mathrm{pH}$ and salinity grades maintained. Also, it fails to attain sexual maturity at $25^{\circ} \mathrm{C}, 30^{\circ} \mathrm{C}$, $35^{\circ} \mathrm{C}$ and room temperatures when fed weed, at all the temperature gradients when maintained with lettuce at $\mathrm{pH} 5$ and 9 , and at $20^{\circ}$ and $35^{\circ} \mathrm{C}$ in all the three salinity grades, and at $25^{\circ} \mathrm{C}$ and room temperatures when the snails were exposed to $2.5 \mathrm{NaCl} \%$ o with the supply of lettuce food. In these experiments the snails exhibited marked variations in the rates of growth in shell length, shell breadth and body weight. In all other experiments the snails were able to complete their life-cycle although significant variations in the rates of growth, multiplication and survival have been noted in respect to the temperatures of the waters of the containers concerned. Also, in most cases the effects of temperature on the life-cycle parameters of $L$. (R.) luteola are influenced by the factors like quality of food, $\mathrm{pH}$, and salinity of water used in experiments. Detailed comparisons in respect to $10^{\circ} \mathrm{C}$ revealed that the effect of $15^{\circ}$ and $20^{\circ} \mathrm{C}$ is significant while at $25^{\circ}, 30^{\circ}, 35^{\circ} \mathrm{C}$ and room temperature the same is significant either at $5 \%$ or $1 \%$ or $0.1 \%$ level when the snails were cultured in waters having three different salinity grades but fed with lettuce.

The overall effect of temperatures $\left(20^{\circ}, 25^{\circ}\right.$, $30^{\circ}, 35^{\circ} \mathrm{C}$ and room temperatures) irrespective of foods is significant at $0.1 \%$ level. From the $\mathrm{F}$ values, it appears that the degree of interaction is almost at the same level as far as the results of $35^{\circ} \mathrm{C}$ and room temperatures are concerned. Though the effect of temperature on the age of attainment of sexual maturity in snails is significant at $0.1 \%$ level throughout, the degree of interaction is gradually higher with the rise of temperature from $20^{\circ}$ to $35^{\circ} \mathrm{C}$ and the impact of room temperature lies in between $30^{\circ}$ and $35^{\circ} \mathrm{C}$. In contrast to this, the effect of $30^{\circ} \mathrm{C}$ is highly significant as far as the duration of reproduction of a snail individual is concerned. However, room temperature has its biggest effect on the rate of egg production, the time required for the development of embryo and the hatchability of eggs. It seems that even under all other similar factors, temperature plays a significant role to regulate the physiology of the snails. As the physiological status of an organism depends greatly on the available food, it is obvious that the life-cycle parameters of snails would vary accordingly. This is dependent on the rate of feeding and conversion of carbohydrate, protein and fat from plant food sources, to snails' body, at various temperatures, as has been discussed by Ahmed and Raut (1991). Since anomalies in longevity in snails cultured at different $\mathrm{pH}$ and salinity of water are well marked at identical temperatures with identical food supply (lettuce) it is assumed that, at least $\mathrm{pH}$ and salinity (since other factors have not been considered in the present study) play important roles in the life process. This is why the snails cultured at $\mathrm{pH} 5$ and 9 in all the temperatures and those cultured in 0.5 , 1.5 and $2.5 \mathrm{NaCl} \%$ at $20^{\circ}$ and $35^{\circ} \mathrm{C}$, in $2.5 \mathrm{NaCl}$ $\% o$ at $25^{\circ} \mathrm{C}$ and room temperature failed to attain sexual maturity. Since the percentage of sexually mature snails varied with the thermal conditions of the water used in cultures, it is apparent that adaptability in snails varied with the individuals. 
TABLE II

Calculated F-values in respect to the effect of temperature on the rates of growth in shell length, shell breadth and body weight of Lymnaea (Radix) luteola cultured with different food, $\mathrm{pH}$ and salinity. The snails considered for experiments with $\mathrm{pH}$ and salinity grades were fed with lettuce

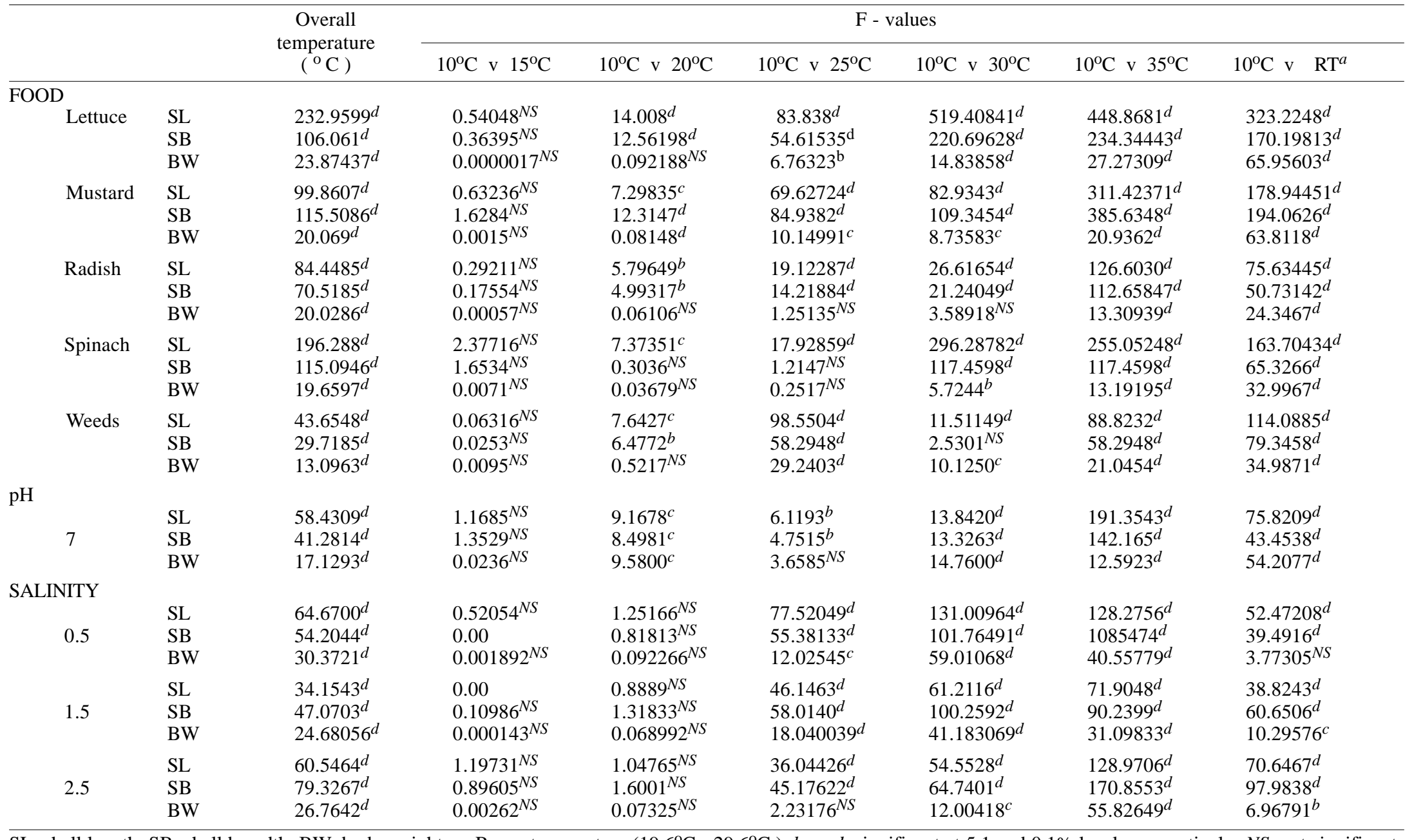


TABLE III

Calculated F-values in respect to the effect of temperature on the longevity and mortality of Lymnaea (Radix) luteola maintained with different foods, $\mathrm{pH}$ and salinity

\begin{tabular}{|c|c|c|c|c|c|c|c|c|}
\hline & & \multirow{2}{*}{$\begin{array}{l}\text { Over all } \\
\text { temperature } \\
\left({ }^{\circ} \mathrm{C}\right)\end{array}$} & \multicolumn{5}{|c|}{$\mathrm{F}$ - values } & \multirow[b]{2}{*}{$10^{\circ} \mathrm{C}$ v RT ${ }^{a}$} \\
\hline & & & $10^{\circ} \mathrm{C}$ v $15^{\circ} \mathrm{C}$ & $10^{\circ} \mathrm{C}$ v $20^{\circ} \mathrm{C}$ & $10^{\circ} \mathrm{C}$ v $25^{\circ} \mathrm{C}$ & $10^{\circ} \mathrm{C}$ v $30^{\circ} \mathrm{C}$ & $10^{\circ} \mathrm{C}$ v $35^{\circ} \mathrm{C}$ & \\
\hline \multirow[t]{3}{*}{ Longevity } & Food & $194.2927^{d}$ & $20.2881^{d}$ & $48.6286^{d}$ & $87.3681^{d}$ & $9.0907^{d}$ & $25.0906^{d}$ & $9.9420^{d}$ \\
\hline & $\mathrm{pH}$ & $0.23739^{N S}$ & - & - & - & - & - & - \\
\hline & Salinity & $4.05357^{c}$ & $0.12208^{N S}$ & $0.0931^{N S}$ & $11.2378^{d}$ & $6.0556^{c}$ & $3.9789^{b}$ & $4.88203^{c}$ \\
\hline \multirow[t]{3}{*}{ Mortality } & Food & $7.48837^{d}$ & $14.6540^{d}$ & $34.5377^{d}$ & $36.0323^{d}$ & $8.1424^{d}$ & $12.4082^{d}$ & $6.4974^{d}$ \\
\hline & $\mathrm{pH}$ & $0.7373^{N S}$ & - & - & - & - & - & - \\
\hline & Salinity & $4.5821^{c}$ & $0.7771^{N S}$ & $6.6492^{c}$ & $3.9344^{b}$ & $13.8731^{d}$ & $20.8134^{d}$ & $0.7388^{N S}$ \\
\hline
\end{tabular}

$a$ : room temperature $\left(19.6^{\circ} \mathrm{C}-29.6^{\circ} \mathrm{C}\right) \quad b, c, d$ : significant at 5,1 and $0.1 \%$ levels, respectively

NS: not significant $\quad-$ : did not compare due to overall insignificant effect

TABLE IV

Calculated F-values in respect to the effect of temperature on the life cycle parameters of Lymnaea ( Radix ) luteola

\begin{tabular}{lccccc}
\hline & \multirow{2}{*}{$\begin{array}{c}\text { Overall } \\
\text { Life cycle parameters }\end{array}$} & \multicolumn{4}{c}{$\mathrm{F}$ - values } \\
\cline { 3 - 6 } & $\left({ }^{\circ} \mathrm{C}\right)$ & $20^{\circ} \mathrm{C}$ v $25^{\circ} \mathrm{C}$ & $20^{\circ} \mathrm{C}$ v $30^{\circ} \mathrm{C}$ & $20^{\circ} \mathrm{C}$ v $35^{\circ} \mathrm{C}$ & $20^{\circ} \mathrm{C}$ v RT \\
\hline Age of attainment of sexual maturity & $11.9278^{d}$ & $10.9894^{d}$ & $29.9788^{d}$ & $31.7239^{d}$ & $27.4537^{d}$ \\
Percentage of snails attained sexual maturity & $21.40902^{d}$ & $34.7113^{d}$ & $58.4479^{d}$ & $54.4861^{d}$ & $46.3688^{d}$ \\
Length of reproduction period & $5.81155^{c}$ & $3.2484^{b}$ & $8.4108^{d}$ & $3.0781^{b}$ & $0.1123^{N S}$ \\
Rate of egg production & $5.11786^{c}$ & $4.6144^{c}$ & $0.0234^{N S}$ & $2.1071^{N S}$ & $5.2031^{c}$ \\
Developmental period of eggs & $28.0615^{d}$ & $21.8266^{d}$ & $18.2256^{d}$ & $75.6797^{d}$ & $82.8493^{d}$ \\
Hatchability percentage of eggs & $21.4329^{d}$ & $28.4455^{d}$ & $17.2704^{d}$ & $6.2343^{c}$ & $7^{c}$ \\
\hline
\end{tabular}

$a$ : room temperature $\left(19.6^{\circ} \mathrm{C}-29.6^{\circ} \mathrm{C}\right) \quad b, c, d$ : significant at 5,1 and $0.1 \%$ levels, respectively $N S$ : not significant

Such adaptability of the snails has been reflected in the length of the reproduction period and the rates of egg production. This phenomenon is also well evident from the facts of variations in the length of the reproduction period and in the rates of egg production in snails exposed to 1.5 and 2.5 $\mathrm{NaCl} \%$. Similar effects of temperature on the rate of growth, reproduction, and behaviour have been noted in Lymnaea stagnalis by Vaughn (1953), in Australorbis glabratus by Michelson (1961), in Bulinus (Physopsis) globosus by Shiff (1964), in Biomphalaria pfeifferi by Sturrock (1966) and Appleton (1977), in Biomphalaria glabrata by Chernin (1967), Sturrock and Sturrock (1972) and Vianey-Liaud (1982), in Biomphalaria pfeifferi by Shiff and Garnett (1967), in Bulinus truncatus and Biomphalaria alexandrina by El-Hassan (1974) and in Indoplanorbis exustus by Raut et al. (1992).

The rate of population growth of a species is very much governed by the length of the incubation period and hatchability of its eggs (if the species is oviparous). Marked variations in the length of the incubation period of the eggs and the percentage of hatching of eggs in respect to temperature have been noted in Lymnaea luteola, $L$. acuminata, I.exustus and Gyraulus convexiusculus (Saha \& Raut 1992). The present findings are in agreement with earlier observations although variations in hatching percentages of the eggs produced by the snails, reared at the same temperature, but fed with different foods, are recorded for the first time. This may be explained by the relationship of stored nutrients in the eggs, to the type of foods consumed by the mother snails concerned. As hatching success of the eggs varied with the $\mathrm{pH}$ and salinity grades it is obvious that these factors have significant influence to alter the beneficial effects of temperature, to a certain extent. The present observations provide a sound basis for understanding the findings of Chitramvong et al. (1981) on Bithynia siamensis siamensis, Radix rubiginosa and Indoplanorbis exustus and of Raut and Misra $(1991,1993)$ on $L$. (R.) luteola, I.exustus and Gyraulus convexius- 
culus .

From the foregoing accounts it appears that the potential of an organism is very much dependent on its ability to adjust to the factors to which it is exposed. Further, it may be stated that the power of adjustment of an organism is determined by its 'genome' (Boughey 1973) or 'dynamic' (Misra \& Raut 1993) factor. Depending upon these factors, the trend of population growth rate in a species as well as the probability of variations in 'strain' are determined. Such studies, from different parts of the globe, although numerous (Newton 1955, Paraense 1955, Richards 1973, Scherrer et al. 1976, Vianey-Liaud 1989, Misra \& Raut 1993), are lacking information on the cumulative effect of different ecological parameters in respect to the strains of the snail species.

\section{ACKNOWLEDGEMENTS}

To the Head, Department of Zoology, University of Calcutta, for providing the necessary facilities.

\section{REFERENCES}

Ahmed M, Raut Sk 1991. Influence of temperature on the growth of the pestiferous land snail Achatina fulica (Gastropoda : Achatinidae). Walkerana 5: 33-62.

Appleton C 1977. Review of literature on abiotic factors influencing the distribution and life cycles of bilharziasis intermediate host snails. Malacol Rev 11: $1-125$.

Berrie AD 1965. On the life cycle of Lymnaea stagnalis (L.) in the west of Scotland. Malacol Soc London Proc 36: 283-295.

Boughey AS 1973. Ecology of population. 2nd ed. Macmillian Publishing Co. Inc., New York, $\mathrm{x}+182$ pp.

Burch JB 1985. Handbook on schistosomiasis and other snail-mediated diseases in Jordan. University of Michigan. Ann. Arbor, Michigan U.S.A. and Ministry of Health, Amman Jordan, i-xv, 224 pp.

Burla H, Speich C 1971. Lymnaea auricularia and Lymnaea ovata im Zürichsee. Rev Suisse Zool 78: 549-556.

Campbell RC 1989. Statistics for biologists. 3rd ed. Cambridge University Press, Cambridge xvii+445 pp.

Chatterjee KD 1952. Human parasites and diseases. The World Press Ltd. Calcutta vi +776 pp.

Chernin E 1967. Behaviour of Biomphalaria glabrata and other snails in a thermal gradient. J Parasitol 53: 1233-1240.

Chitramvong YP, Upathan ES, Sukhapanth N 1981. Effect of some physico-chemical factors on the survival of Bihynia siamensis siamensis, Radix rubiginosa and Indoplanorbis exustus. Malacol Rev 14: 43- 48 .

El-Hassan A 1974. Laboratory studies on the direct effect of temperature on Bulinus truncatus and Biomphalaria alexandrina, the snail intermediate hosts of schistosomes in Egypt. Folia Parasitol Czechol 21: 181-187.
Ghosh RK, Chauhan BS 1975. Fifty years of faunistic survey in India. Rec zool Surv Ind 68: 367-381.

Godan D 1983. Pest slugs and snails. Springer-Verlag, Berlin, Heidelberg, New York vi + 445 pp.

Hunter RD 1975. Growth, fecundity and bioenergetics in three population of Lymnaea palustris in upstate New York. Ecology 56: 50-63

Jong-Brink M De 1990. How trematode parasites interfere with reproduction of their intermediate hosts freshwater snails. J Med Appl Malacol 2: 101-133.

Kendall SB 1953. The life history of Lymnaea truncatula under laboratory conditions. Helminth 27: $17-28$.

Liston WG, Soparkar MB 1918. Bilharziasis among animals in India. The life-cycle of Schistosomum spindalis. Ind J Med Res 5: 567-569.

Magnuson JJ, Crosder LB, Medvick PA 1979. Temperature as an ecological resource. Amer Zool 19: 331-343.

Malek EA, Cheng TC 1974. Medical and Economic Malacology. Academic press, New York, London, $408 \mathrm{pp}$.

McCraw BM 1970. Aspects of the growth of the snail Lymnaea palustris ( Muller ). Malacologia 10: 399-413 .

Michelson EH 1961. The effects of temperature on growth and reproduction of Australorbis glabratus in the laboratory. Am J Hyg 73: 66-74 .

Misra TK, Raut SK 1993. Dynamic of populationdynamics in a medically important snail species Lymnaea (Radix) luteola (Lamarck). Mem Inst Oswaldo Cruz 88: 469-485

Moens R 1991. Factors affecting Lymnaea truncatula populations and related control measures. J Med Appl Malacol 3: 73-84 .

Noland LE, Carriker MR 1946. Observations on the biology of the snail Lymnaea stagnalis appressa during twenty generations in laboratory culture. Amer Midland Naturalist 36: 467-493 .

Newton WL 1955. The establishment of a strain of Australorbis glabratus which combines albinism and high susceptibility to infection with Schistosoma mansoni. J Parasitol 41: 526-528.

Paraense W 1955. Self and cross-fertilization in Australorbis glabratus. Mem Inst Oswaldo Cruz 53: 285-291.

Precht H, Christopherson J, Hensel, H, Larcher A 1973. Temperature and life. Springer-Verlag, Berlin $\mathrm{xi}+315 \mathrm{pp}$.

Prinsloo JF, Van Eeden JA 1969. Temperature and its bearing on the distribution and chemical conrol of freshwater snails. S Afr med J 43:1363-1365.

Prinsloo JF, Van Eeden JA 1973. The influence of temperature on the growth rate of Bulinus (Bulinus) tropicus (Krauss) and Lymnaea natalensis (Krauss) (Mollusca:Basommatophora). Malacologia 14: 81-88.

Rao MAN 1933. A preliminary report on the successful infection with nasal schistosomiasis in experimental calves. Ind J Vet Sci Anim Husb 3: 160-162.

Raut Sk 1986. Snails and slugs in relation to human 
diseases. Environment Ecology 4: 130-137.

Raut SK, Misra TK 1991. Effect of salinity on the growth of three medically important snail species. Boll Malacologico ROC 16 : 67-74.

Raut SK, Misra TK 1993. Influence of salinity on the breeding of three medically important freshwater snail species (Gastropoda : Basommatophora: Lymnaeidae et Planorbidae). Malakol Abh Mus Tierkd Dresden $16: 173-176$.

Raut SK, Rahaman MS, Samanta SK 1992. Influence of temperature on survival, growth and fecundity of the freshwater snail Indoplanorbis exustus (Deshayes). Mem Inst Oswaldo Cruz 87: 15-19.

Richards CS 1973. Pigmentation variations in Biomphalaria glabrata and other Planorbidae. Malacol Rev 61: 49-51.

Saha TC, Raut SK 1992. Bioecology of the water-bug Sphaerodema annulatum Fabricius. Arch Hydrobiol 124: 239-253.

Scherrer JF, de Chquilof MAG, Freitas JR 1976. Estudo comparativo da reprodução em quatro variedades genéticas de Biomphalaria glabrata (Say, 1818). I-Fecundidade. Rev Inst Med Trop S Paulo 18: 315-321.

Seshaiya RV 1927. On the breeding habits and fecundity of the snail Lymnaea luteola Lamarck (Formatypica). J Bombay nat Hist Soc 32: 154-158.

Shiff CJ 1964. Studies on Bulinus (Physopsis) globosus in Rhodesia. II. Factors influencing the relationship between age and growth. Ann Trop Med Parasitol 58: 106-115.

Shiff CJ, Garnett BG 1967. The influence of temperature on the intrinsic rate of natural increase of the freshwater snail Biomphalaria pfeifferi
(Krauss) (Pulmonata : Planorbidae). Arch Hydrobiol $62: 429-438$.

Sturrock RF 1966. The influence of temperature on the biology of Biomphalaria pfeifferi (Krauss), an intermediate host of Schistosoma mansoni. Ann Trop Med \& Parasitol 60: 100-105.

Sturrock RF, Sturrock BA 1972. The influence of temperature on the biology of Biomphalaria glabrata (Say), intermediate host of Schistosoma mansoni in St. Lucia, West Indies. Ann Trop Med Parasitol 66: 385-390.

Van Der Borght SCK, Van Puymbroeck S 1971. Kinetics of the direct uptake of $\mathrm{Ca}$ and $\mathrm{Sr}$ ions from water by freshwater Gastropods : Influence of temperature. Environ Physiol 1: 83-95.

Van Der Steen WJ, Jager JC, Timersma D 1973. The influence of food quality on feeding, reproduction and growth in the pond snails Lymnaea stagnalis (L.) with some methodological comments. Proc $K$ Med Akod Wet (Ser. C) 76: 47-60.

Vaughn ChM 1953. Effects of temperature on hatching and growth of Lymnaea stagnalis appressa Say. Amer Midland Naturalist 49: 214-228.

Vianey-Liaud M 1982. Effects des hautes temperatures sur la reproduction de Biomphalaria glabrata (Mollusca: Basommatophora). (Proc 7th Intern Malacol Congr). Malacologia 22: 159-165.

Vianey-Liaud M 1989. Growth and fecundity in a blackpigmented and an albinostrain of Biomphalaria glabrata (Gastropoda : Pulmonata). Malacol Rev 22: $25-32$.

Walter HJ 1968. Evolution, taxonomy revolution and zoogeography of the Lymnaeidae. Amer Malacol Union Ann Rep 35: 18-20. 